\title{
Juvenile development of Callinectes danae Smith, 1869 (Crustacea, Decapoda, Brachyura, Portunidae) under laboratory conditions
}

\author{
EDUARDO A. BOLLA Jr ${ }^{1}$, VIVIAN FRANSOZO ${ }^{2}$ and MARIA LUCIA NEGREIROS-FRANSOZO ${ }^{1}$ \\ ${ }^{1}$ NEBECC, Departamento de Zoologia, Instituto de Biociências de Botucatu, Universidade Estadual Paulista/ UNESP, \\ Distrito de Rubião Júnior, s/n, Caixa Postal 510, 18618-970 Botucatu, SP, Brasil \\ ${ }^{2}$ Departamento de Ciências Naturais - Zoologia, Universidade Estadual do Sudoeste da Bahia/ UESB, Estrada do Bem Querer, \\ Km 04, Campus de Vitória da Conquista, Caixa Postal 95, Bairro Universidade, 45031-900 Vitória da Conquista, BA, Brasil
}

Manuscript received on November 23, 2012; accepted for publication on March 28, 2013

\begin{abstract}
The juvenile development of Callinectes danae was investigated from megalopae obtained in neuston samples at Ubatuba, São Paulo, Brazil. The individuals were raised in the laboratory under constant temperature $\left(25 \pm 1{ }^{\circ} \mathrm{C}\right)$, filtered sea water from the collection location $(35 \%)$, and natural photoperiod. Newly hatched Artemia sp. nauplii were offered as food on a daily basis and ornamental-fish food was also provided for the juveniles from the $4^{\text {th }}$ stage on. Twelve stages of the juvenile phase were obtained. The main morphological features that allowed recognition of the first juvenile stage were drawn and described. All the subsequent stages obtained were examined and measured, and the main changes in relation to the first stage were recorded. Sexual dimorphism becomes apparent from the fourth juvenile stage onwards. Some appendages and morphological features proved to be of great importance in the identification of species, including the number of segments of the antennal flagellum and the number of setae on the maxilla and on the $1^{\text {st }}, 2^{\text {nd }}$ and $3^{\text {rd }}$ maxillipeds. These can probably be used for future comparisons and species identifications.
\end{abstract}

Key words: juvenile stages, morphology, portunid, post-larval, swimming crab.

\section{INTRODUCTION}

The life cycle of marine brachyurans, in general, has two distinct periods, the planktonic and the benthic. Each phase has its own particularities, which can be reflected in the animal's development, mainly during the change from the larval to the juvenile phase (Kurata 1962). The planktonic period comprises the larval development, which includes a zoea phase with several zoeal stages, and a final megalopa phase with a unique megalopa stage, whose settlement marks the transition between the planktonic and the benthic

Correspondence to: Eduardo Antonio Bolla Jr

E-mail: bollajr@ibb.unesp.br period (Anger 2001). In the benthic period, early development up to the pubertal molt is characterized as the juvenile phase. This phase comprises a few early "undifferentiated" stages (characterized by a non-external sexual differentiation of the individual) and "immature" stages, during which juveniles can be sexed by observing the number of pleopods on their abdomen. Only in the later immature stages the gonads begin to differentiate, and usually the relative growth of certain body parts starts to differ slightly between the sexes (Hartnoll 1982).

The undifferentiated stages can vary in number, from one in Pachygrapsus transversus (Gibbes, 1850), 
studied by Flores et al. (1998), to eleven stages in Sesarma rectum Randall, 1840, described by Fransozo (1986/87). The undifferentiated stages end with the pre-pubertal molt followed by the first immature stage. The immature juveniles can show a highly variable number of stages and when the individual reaches sexual maturity at the puberty molt, the adult phase begins. As the study of juvenile development in decapods is still incipient, the nomenclature of the terms "phase" and/or "stages" is also variable. Some authors use different nomenclatures for the stages in juvenile phase in several species. In most cases they do not use the separation between undifferentiated and immature stages. However, we adopted here the concept described above.

Studies of the early life cycle of crabs amplify taxonomic knowledge and also provide information on their ecology, physiology, phylogeny, and so on (Felder et al. 1985, Anger 2001). A pioneer complete study on juvenile development in Brachyura was accomplished by Shen (1935), who described Carcinus maenas (Linnaeus, 1758) (Portunidae) up to the ninth stage of the juvenile phase. Studies in the following decades dealt mostly with the description of the first stage of the juvenile phase. More complete descriptions appeared again during the 1980s. The species for which the juvenile development has been studied and which occur on the Brazilian coast are listed in Table I.

The family Portunidae Rafinesque, 1815 is represented on the Brazilian coast by 21 species (Melo 1996, Calado 1996, Carqueija and Gouvêa 1996, Tavares and Mendonça Jr 1996) of which 6 belong to the genus Callinectes. The geographical distribution of Callinectes danae Smith, 1869 includes much of the Western Atlantic: Bermuda, Florida, Gulf of Mexico, Antilles, Colombia, Venezuela and Brazil (from the states of Paraíba to Rio Grande do Sul). This crab occurs from brackish to hypersaline waters, in mangroves and muddy estuaries, on sandy beaches to the open sea, and from the intertidal zone to $75 \mathrm{~m}$ depth (Melo 1996).
In the family Portunidae, juvenile development has been described for a relatively small number of species. For the genus Callinectes, only $C$. sapidus Rathbun, 1896 and C. ornatus Ordway, 1863 have been studied, both up to the $11^{\text {th }}$ stages of the juvenile phase, by Barutot et al. (2001) and Bolla Jr et al. (2008), respectively. Ogburn et al. (2011) also studied some species of portunids, but only superficial descriptions of the carapace of C. sapidus and C. similis were provided. Due to the scarcity of investigations on this aspect, it is difficult to define characteristics that are peculiar in the juvenile phase for portunids. Only detailed studies from laboratory rearing will allow the comparison and the establishment of features for portunid species.

This study presents morphological details and the most significant features that identify the juvenile phase of $C$. danae. We also provide information to recognize this species in natural environments, during its juvenile phase. This information will contribute to species identification and culture for economic purposes.

\section{MATERIALS AND METHODS}

The juvenile development of $C$. danae was studied using material from the collection of larvae and juveniles of the "Núcleo de Estudos em Biologia, Ecologia e Cultivo de Crustáceos (NEBECC)", Departamento de Zoologia, Instituto de Biociências, UNESP, Botucatu, São Paulo, Brazil. This material consisted of juveniles (exuviae and individuals) obtained from raising of megalopae captured in the neuston of Ubatuba Bay $\left(23^{\circ} 26^{\prime} \mathrm{S} ; 4^{\circ} 03^{\prime} \mathrm{W}\right)$, Ubatuba/SP. The climate was tropical/subtropical, with mean temperatures of water surface around $18^{\circ} \mathrm{C}$ during winter and $29^{\circ} \mathrm{C}$ during summer (Negreiros-Fransozo and Fransozo 2003).

The megalopae were collected using neuston nets $(500 \mu \mathrm{m}$ mesh $)$ in ten minutes of trawling, at night, from September to February 2005/2006 and 2006/2007. After collection and sorting, the 
TABLE I

List of species with occurrence in the Brazilian coast, with some stages of the juvenile phase known to date.

\begin{tabular}{|c|c|c|c|c|}
\hline $\begin{array}{l}\text { Super } \\
\text { Families }\end{array}$ & Species & $\begin{array}{c}\text { Juvenile } \\
\text { stages } \\
\text { described }\end{array}$ & $\begin{array}{c}\text { Stage of } \\
\text { the sexual } \\
\text { differentiation } \\
\text { (based on } \\
\text { pleopods) } \\
\end{array}$ & Authors \\
\hline Aethroidea & Hepatus pudibundus (Herbst, 1785) & $1^{\text {st }}$ to $8^{\text {th }}$ & $3^{\text {rd }}$ & Hebling and Rieger 2003 \\
\hline \multirow{6}{*}{ Grapsoidea } & Armases rubripes (Rathbun, 1897) & $1^{\text {st }}$ to $10^{\text {th }}$ & $5^{\text {th }}$ & Negreiros-Fransozo et al. 2011 \\
\hline & Cyrtograpsus angulatus Dana, 1851 & $1^{\text {st }}$ to $13^{\text {th }}$ & $4^{\text {th }}$ & Rieger and Beltrão 2000 \\
\hline & $\begin{array}{l}\text { Neohelice granulata (Dana, 1851) (described } \\
\text { as Chasmagnathus granulata) }\end{array}$ & $1^{\text {st }}$ to $8^{\text {th }}$ & $3^{\mathrm{rd}}$ & Rieger and Nakagawa 1995 \\
\hline & Pachygrapsus transversus (Gibbes, 1850) & $1^{\text {st }}$ to $8^{\text {th }}$ & $3^{\text {rd }}$ & Flores et al. 1998 \\
\hline & Percnon gibbesi (H. Milne-Edwards, 1853) & $1^{\mathrm{st}}$ & $?$ & Paula and Hartnoll 1989 \\
\hline & Sesarma rectum Randall, 1840 & $1^{\text {st }}$ to $15^{\text {th }}$ & $12^{\text {th }}$ & Fransozo 1986/87 \\
\hline Majoidea & Pyromaia tuberculata (Lockington, 1877) & $1^{\text {st }}$ to $9^{\text {th }}$ & $2^{\text {nd }}$ & Flores et al. 2002 \\
\hline \multirow{2}{*}{ Ocypodoidea } & Uca (Leptuca) cumulanta Crane, 1943 & $1^{\text {st }}$ to $8^{\text {th }}$ & $3^{\text {rd }}$ & Hirose et al. 2010 \\
\hline & Uca (Minuca) burgersi Holthuis, 1967 & $1^{\text {st }}$ to $10^{\text {th }}$ & $4^{\text {th }}$ & Vieira et al. 2010 \\
\hline \multirow{4}{*}{ Portunoidea } & Arenaeus cribrarius (Lamarck, 1818) & $1^{\mathrm{st}}$ to $3^{\mathrm{rd}}$ & $?$ & Stuck and Truesdale 1988 \\
\hline & Callinectes ornatus Ordway, 1863 & $1^{\text {st }}$ to $11^{\text {th }}$ & $4^{\text {th }}$ & Bolla Jr et al. 2008 \\
\hline & Callinectes sapidus Rathbun, 1896 & $1^{\text {st }}$ to $11^{\text {th }}$ & $4^{\text {th }}$ & Barutot et al. 2001 \\
\hline & Charybdis hellerii (A. Milne-Edwards, 1867) & $1^{\text {st }}$ to $3^{\text {rd }}$ & $?$ & Dineen et al. 2001 \\
\hline \multirow{9}{*}{ Xanthoidea } & $\begin{array}{l}\text { Acantholobulus bermudensis (Stimpson, } \\
\text { 1871) (described as Hexapanopeus heblingi) }\end{array}$ & $1^{\text {st }}$ to $14^{\text {th }}$ & $6^{\text {th }}$ & $\begin{array}{c}\text { Martin et al. 1984, M.D. Rodrigues, } \\
\text { unpublished data }\end{array}$ \\
\hline & Eriphia gonagra (Fabricius, 1871) & $1^{\text {st }}$ to $10^{\text {th }}$ & $4^{\text {th }}$ & $\begin{array}{c}\text { Fransozo and Negreiros-Fransozo } \\
1987\end{array}$ \\
\hline & Eurypanopeus abbreviatus (Stimpson, 1860) & $1^{\text {st }}$ to $7^{\text {th }}$ & $4^{\text {th }}$ & $\begin{array}{c}\text { Fransozo and Negreiros-Fransozo } \\
1987\end{array}$ \\
\hline & Eurytium limosum (Say, 1818) & $1^{\text {st }}$ to $10^{\text {th }}$ & $4^{\text {th }}$ & $\begin{array}{l}\text { Guimarães and Negreiros-Fransozo } \\
2005\end{array}$ \\
\hline & Hexapanopeus caribbaeus Stimpson, 1871 & $1^{\text {st }}$ to $11^{\text {th }}$ & $5^{\text {th }}$ & R.R.R.Vieira, unpublished data \\
\hline & Menippe nodifrons Stimpson, 1859 & $1^{\text {st }}$ to $8^{\text {th }}$ & $4^{\mathrm{th}}$ & Fransozo et al. 1988 \\
\hline & $\begin{array}{l}\text { Panopeus austrobesus Williams, } 1983 \\
\text { (described as Panopeus herbstii) }\end{array}$ & $1^{\text {st }}$ to $15^{\text {th }}$ & $4^{\text {th }}$ & Hebling et al. 1982 \\
\hline & Panopeus occidentalis Saussure, 1857 & $1^{\text {st }}$ to $14^{\text {th }}$ & $6^{\text {th }}$ & M.D. Rodrigues, unpublished data \\
\hline & Panopeus rugosus A. Milne-Edwards, 1880 & $1^{\text {st }}$ to $14^{\text {th }}$ & $6^{\text {th }}$ & M.D. Rodrigues, unpublished data \\
\hline
\end{tabular}

$?=$ the authors did not mention or did not get the stage in which the sexual differentiation occurs.

megalopae were separated into covered acrylic containers $(30 \mathrm{ml})$ with filtered sea water (salinity 35) from the sampling area, and transported to the NEBECC laboratory. The megalopae were individually raised at $24 \pm 1^{\circ} \mathrm{C}$ in labeled and numbered containers with filtered and aerated sea water. The containers were inspected daily, and debris and exuviae or dead individuals were removed. The water in the containers was partially renewed over one day, and completely replaced every second day with filtered and aerated sea water. After inspection, individuals were fed with newly hatched Artemia sp. nauplii ad libitum and, for juveniles from $4^{\text {th }}$ stage on, ornamental-fish food was also provided. Dead individuals and their respective exuviae were fixed in $80 \%$ ethanol and glycerin at 2:1, and stage changes and deaths were recorded. These techniques are similar to those used by Guimarães and Negreiros-Fransozo (2005) and Negreiros-Fransozo et al. (2007). 
All individuals in the different stages were dissected, measured, drawn, and described based on fixed exuviae and dead individuals, using a stereoscopic microscope (Zeiss SV6) or a compound optical microscope (Zeiss Axioskop 2, with Nomarski optics), both equipped with a drawing tube, ocular micrometer, and Axiovision image system.

At least ten individuals of the first stage of the juvenile phase (J1) were dissected, drawn, and analyzed with regard to their structure and the number and types of setae. In addition, at least three specimens of each of the following stages were dissected and analyzed for evidence of morphological changes over the developmental period. These changes were recorded in tables, and the most noticeable changes were illustrated with line drawings.

The terminology adopted for the descriptions was based on Clark et al. (1998) and Pohle et al. (1999). Setae types were named according to Pohle (1989) and Garm (2004). The setal sequence was presented from the proximal to the distal part of the appendages. Systematic classifications were based on $\mathrm{Ng}$ et al. (2008).

\section{RESULTS}

During the rearing experiments of $C$. danae, the juvenile development was followed until the $12^{\text {th }}$ stage, when the last specimen died.

\section{Morphology of the First Stage of $C$. danae}

The general shape of the first stage (Fig. 1a) was similar to that of the adult: carapace flattened dorso-ventrally, slightly convex, wider than long, and two small frontal teeth. It also presented: eight finely serrate lateral spines plus the pair of spines common to portunids; small plumose setae on the orbital margin and small granules and sparse simple setae over the carapace surface, in addition to welldeveloped stalked eyes.

Antennule (Fig. 2b) had a developed basal segment bearing several plumose and simple setae; numerous small marginal granules; bisegmented peduncle with sparse simple setae; bisegmented endopod (ventral flagellum) with, respectively, 3 and 10 simple setae on the proximal and distal segments; exopod (dorsal flagellum) constituted by 7 segments with $0,14,10,8,5,0$ and 0 long aesthetascs from the proximal to the distal segment, respectively. Exopod with 0, 1, 2, 3, 1, 4 and 3 simple setae from the proximal to the distal segment.

Antenna (Fig. 2a) bore a 3-segmented antennal peduncle, provided with simple and plumose setae. Antennal flagellum 10-segmented with 0, 2, 4, 2, 2, 2, 3, 2, 4 and 3 simple setae, all of them terminal.

Mandible (Fig. 2c) possessed an incised, well chitinized blade; palp 3-segmented with 2 serrate and 14 plumose setae on the distal segment and 1 long plumose seta on the middle segment.

Maxillule (Fig. 2e) exhibited a coxal endite with 2 plumose setae, 15 simple setae of several sizes and 2 serrate setae; basial endite with 4 small simple setae and 1 long seta on the proximal margin, 6 serrate setae, 9 simple, 7 cuspidate and 3 plumose on distal margin; bisegmented endopod with 3 plumose setae and 1 simple seta on proximal segment, and 3 plumose setae and 2 simple setae on the distal segment. Two simple setae on protopod margin.

Maxilla (Fig. 2d) had a bilobed coxal endite with 6 plumose setae and 1 simple seta on the proximal segment, 2 simple setae and 6 plumose setae on the distal segment; basial endite, bilobed, with 3 plumose setae and 7 simple setae on the proximal segment, 3 plumose setae and 13 simple setae on the distal segment; endopod with 1 plumose and 4 simple marginal setae; exopod (= scaphognathite) with 85 plumose marginal setae and 63 simple surface setae.

First Maxilliped (Fig. 3a) bore a coxal endite with 15 plumose, 10 serrate, 5 simple setae and 3 plumo-denticulate setae; basial endite with 36 plumose setae, 13 serrate and 9 small simple setae; unsegmented endopod with 8 plumose setae and 4 simple setae in proximal region, 22 simple marginal setae and 1 sparsely plumose seta on distal region, 

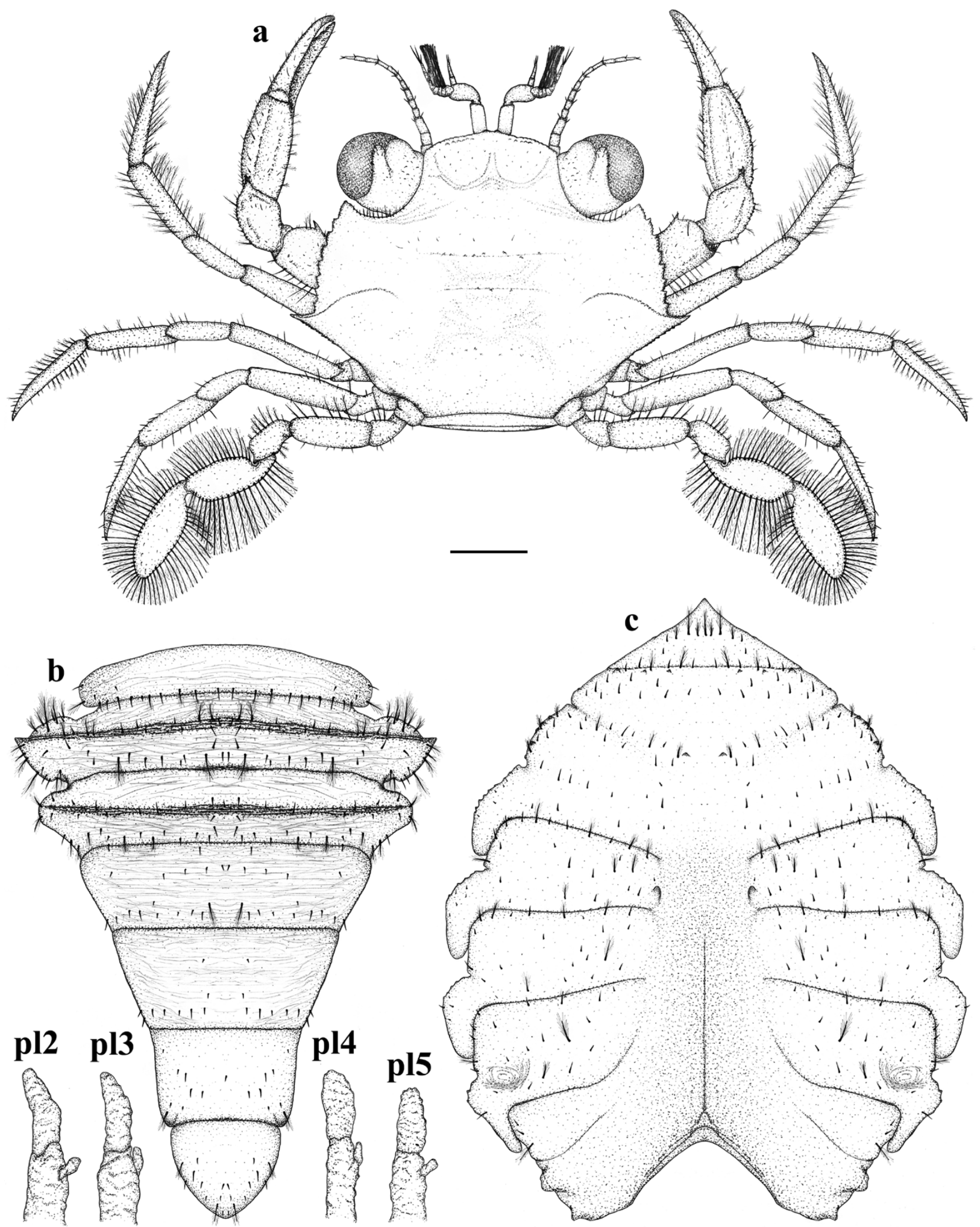

Figure 1 - Callinectes danae. $1^{\text {st }}$ undifferentiated stage: A, dorsal view; B, abdomen (dorsal view); C, sternum (ventral view); pl2-pl5, rudimentary pleopods (from $2^{\text {nd }}$ to $5^{\text {th }}$ abdominal somites). Scale: $\mathbf{A}, 0.5 \mathrm{~mm} ; \mathbf{B}, \mathbf{C}$ and pl2-pl5, 0.2mm. 


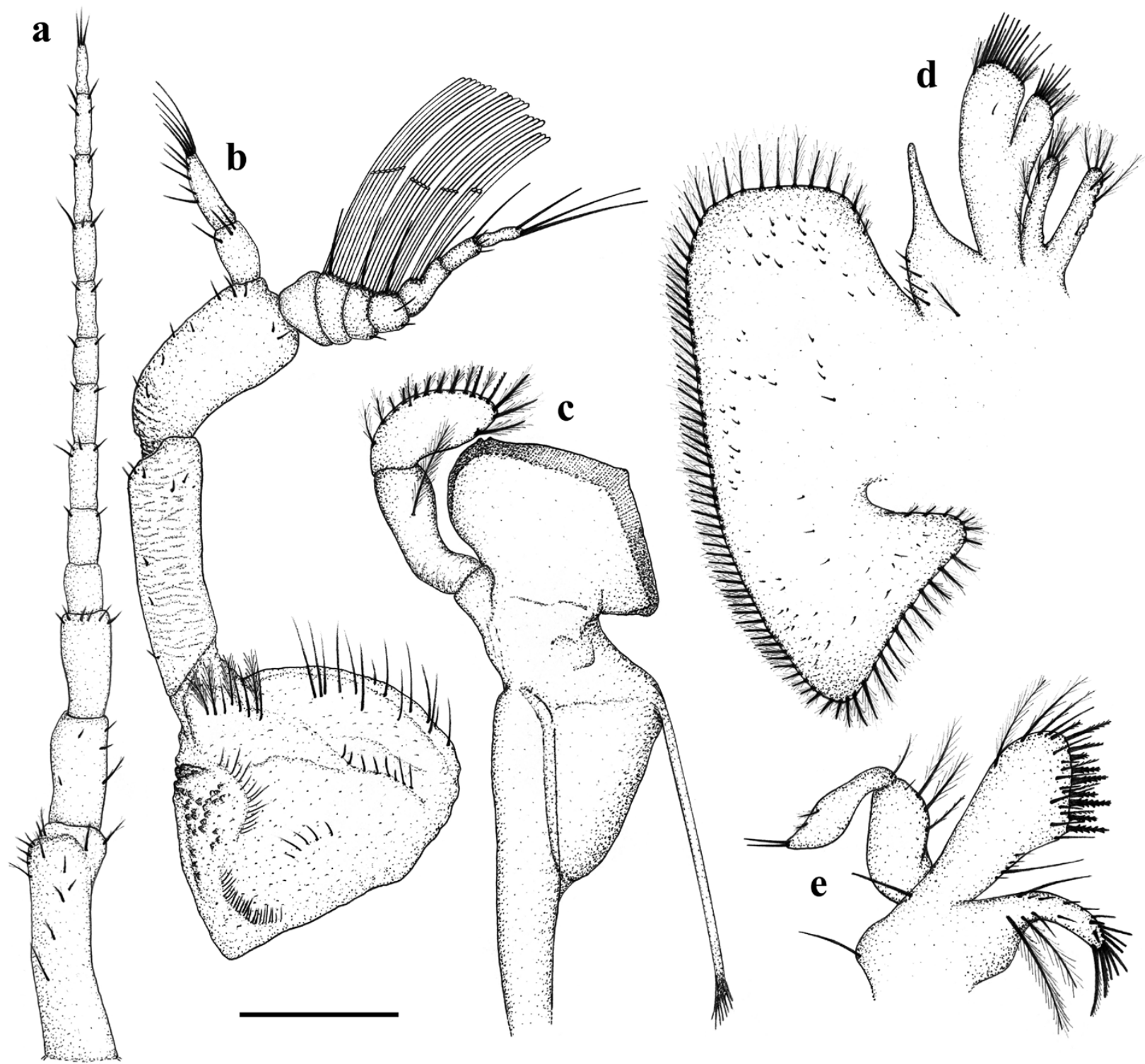

Figure 2 - Callinectes danae. $1^{\text {st }}$ undifferentiated stage: A, antenna; B, antennules; C, mandible; D, maxilla; E, maxillule. Scale: $0.2 \mathrm{~mm}$.

1 small seta on the shaft of this region; bisegmented exopod with 13 plumose, 2 simple and 5 cuspidate setae on the proximal segment, 7 plumose and 5 simple setae on the distal segment; epipod well developed, with 58 simple setae.

Second Maxilliped (Fig. 3b) possessed a 5-segmented endopod with 6, 8, 2, 1 and 0 plumose setae from the proximal to the distal segment, 3 and 4 serrate setae and 0 and 5 cuspidate setae, on the $4^{\text {th }}$ and $5^{\text {th }}$ segments, respectively; and 5,
16, 4, 11 and 5 simple setae from the proximal to the distal segment; bisegmented exopod with 9 plumose setae, 18 simple setae and 8 cuspidate setae on the proximal segment, 3 simple setae and 6 plumose setae on the distal segment; protopod with 3 plumose setae and 6 simple setae; rudimentary epipod provided with 3 simple setae.

Third Maxilliped (Fig. 3c) exhibited a 5 -segmented endopod with several marginal spines on the first and second segments, several 


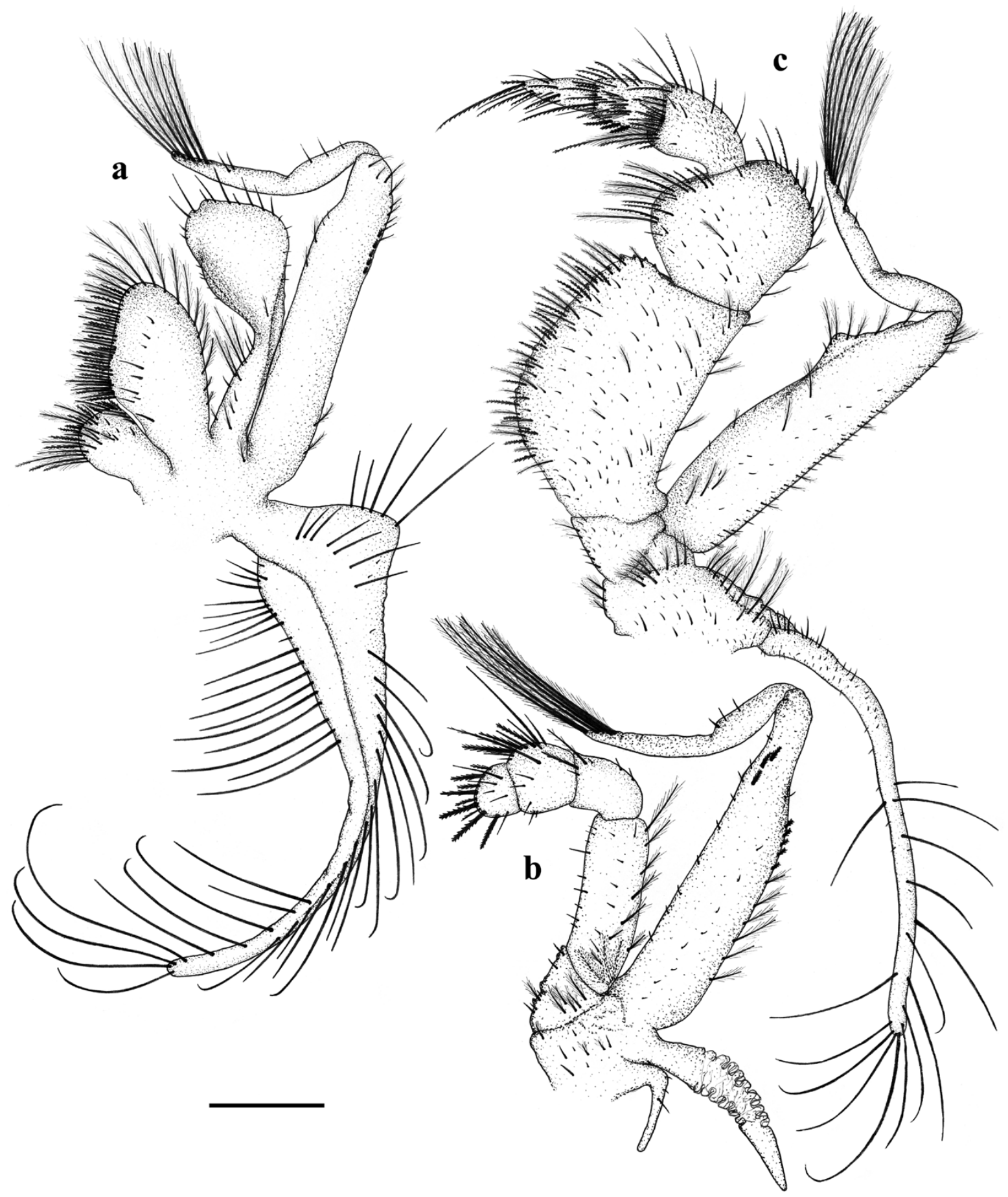

Figure 3 - Callinectes danae. $1^{\text {st }}$ undifferentiated stage: $\mathbf{A}, 1^{\text {st }}$ maxilliped; $\mathbf{B}, 2^{\text {nd }}$ maxilliped; $\mathbf{C}, 3^{\text {rd }}$ maxilliped. Scale: $0.2 \mathrm{~mm}$.

setae on each segment: $17,11,12,19$ and 6 serrate setae, 35, 11, 1, 0, 0 plumose setae, 0,0 , $5,4,0$ plumodenticulate setae and $63,21,9,5,7$ simple setae from the proximal to distal segment; bisegmented exopod with 24 plumose setae and 45 simple setae on the proximal segment and 8 plumose and 2 simple setae on the distal; protopod with 22 plumose setae of several sizes and 44 small 
simple setae; epipod with around 53 small simple setae on the proximal portion and 15 long simple setae on the distal portion.

Chelipeds (Fig. 4a) were symmetrical, with marginal spines and three strong inner ones on merus; granules and small spines on external margin of the carpus and propodus; simple and plumose setae sparsely distributed over the appendage surface, plus long plumose setae on the external margin of the merus. Second, third (Fig. 4b) and fourth pereiopods similar, sparse simple setae and several plumose setae present, mainly on the inner and external margins of the propodus and dactyls.
Last pair of pereiopods (Fig. 4c) - a spine on the coxa; propodus and dactyl flattened and paddleshaped with several marginal plumose setae.

Thoracic sternites (Fig. 1c) had simple and plumose setae sparsely distributed over surface; concentric and semicircular wrinkle on the $7^{\text {th }}$ somite (near the coxa).

Abdomen (Fig. 1b) bore 6 somites, wider than long, several sparse simple and plumose setae; the first 5 somites with horizontal ridges; telson smooth with small simple and plumose setae. Rudimentary pleopods visible ventrally on the $2^{\text {nd }}$ to $5^{\text {th }}$ somites (Fig. 1, $\mathrm{PL}_{2}-\mathrm{PL}_{5}$ ).

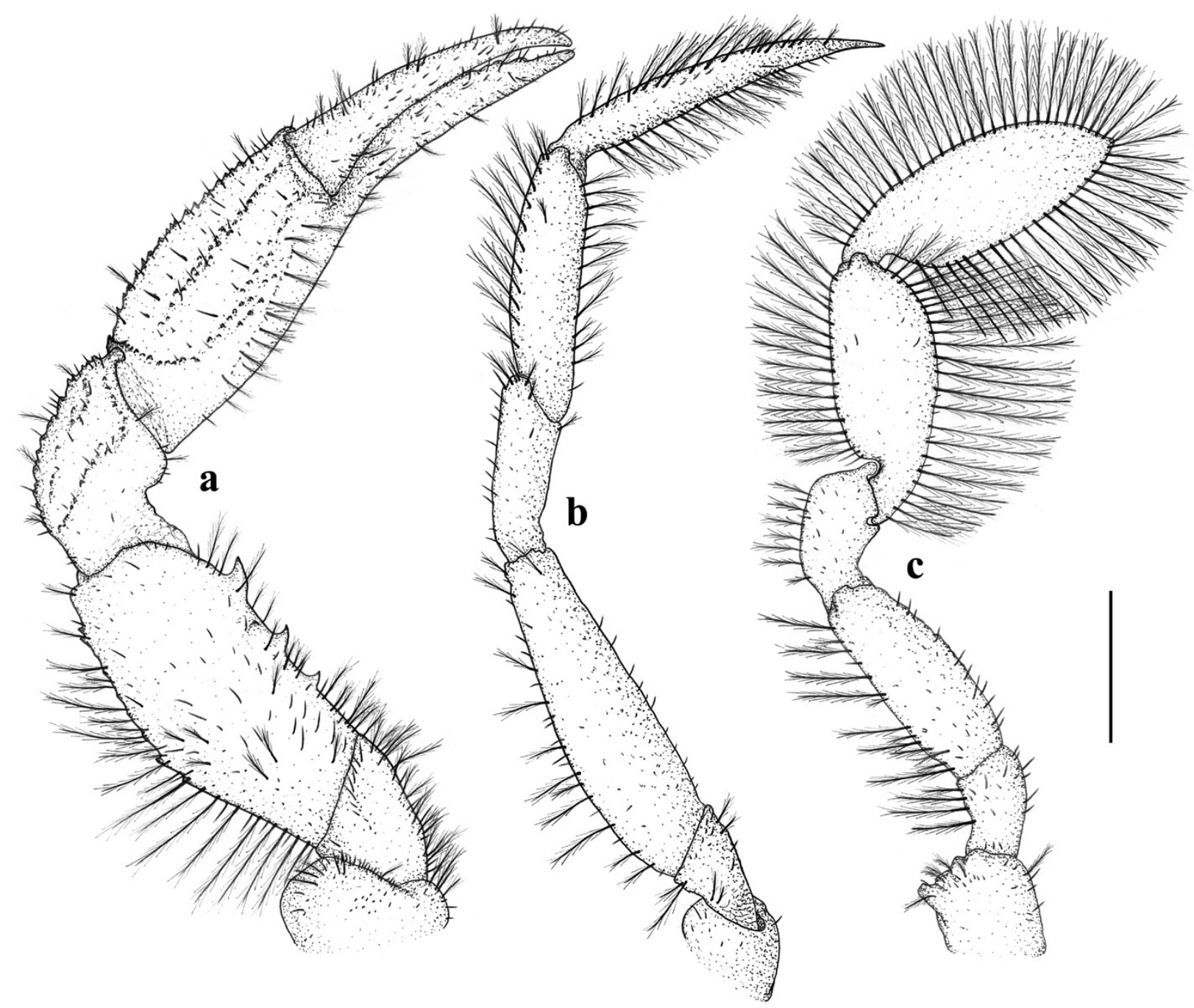

Figure 4 - Callinectes danae. $1^{\text {st }}$ undifferentiated stage: $\mathbf{A}$, cheliped; $\mathbf{B}, 3^{\text {rd }}$ pereopod; $\mathbf{C}, 5^{\text {th }}$ pereopod. Scale: $0.4 \mathrm{~mm}$. 
Morphology OF THE $2^{\text {nd }}$ TO $12^{\text {th }}$ StAGES OF $C$. danae

As the individuals grew in the following stages, in each successive ecdysis the proportion between carapace width and carapace length varied very little. This proportion reached the same as observed in the adult phase, from the $12^{\text {th }}$ stage on (Fig. 5a).
The abdomen increased in size during the growth period, but it changed slightly in shape; the sex of individuals could be distinguished only at the $12^{\text {th }}$ stage. As observed in adult swimming crabs, the male abdomen had an inverted " $\mathrm{T}$ " shape and the female abdomen was semicircular (Fig. 5, $\mathrm{J}_{4}-\mathrm{J}_{12}$ ).

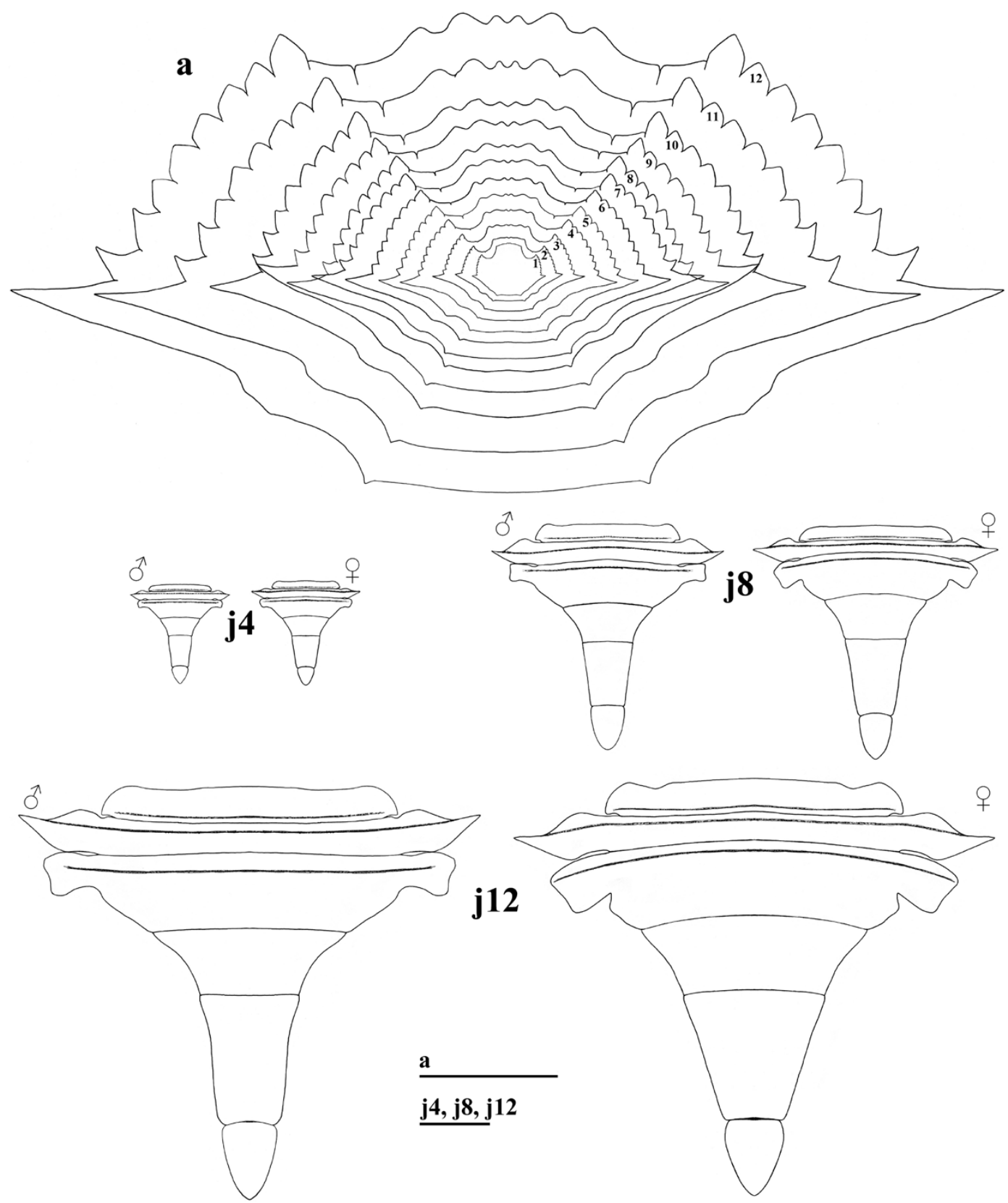

Figure 5 - Callinectes danae. A, carapace development throughout all juvenile stages obtained (numbers represent the stage of the juvenile phase); $\mathbf{j 4}, \mathbf{j} \mathbf{8}$ and $\mathbf{j 1 2}$, development of the abdomen shape of both males and females in $4^{\text {th }}, 8^{\text {th }}$ and $12^{\text {th }}$ stages, respectively. Scale: A, 5mm; j4-j12, $2 \mathrm{~mm}$. 
The most remarkable morphological changes, observed as of the $2^{\text {nd }}$ stage, were related to the secondary sexual characteristics. The existing rudimentary pleopods in the $1^{\text {st }}$ stage disappeared in the $2^{\text {nd }}$ stage. In the $4^{\text {th }}$ stage the pleopods reappeared, but in different numbers and locations, according to each sex, as follows:

Male: two pairs of pleopods on the first $\left(\mathrm{PL}_{1}\right)$ and second $\left(\mathrm{PL}_{2}\right)$ somite of the abdomen, $\mathrm{PL}_{2}$ with one reduced rami (Fig. $6, \mathrm{~J}_{4}$ ). In the $5^{\text {th }}$ and $6^{\text {th }}$ stages (Fig. $6, \mathrm{~J}_{5}$ and $\mathrm{J}_{6}$ ) no significant changes, $\mathrm{PL}_{1}$ only increased in size. In the $7^{\text {th }}$ and $8^{\text {th }}$ stages (Fig. 6, $\mathrm{J}_{7}$ and $\mathrm{J}_{8}$ ), $\mathrm{PL}_{2}$ exhibited one reduced rami and $\mathrm{PL}_{1}$ had plumose setae on its base and simple setae along its length. From the $9^{\text {th }}$ stage on (Fig. 7, $\left.\mathrm{J}_{9}-\mathrm{J}_{12}\right), \mathrm{PL}_{2}$ was uniramous and both $\mathrm{PL}_{1}$ and $\mathrm{PL}_{2}$ were gradually larger, with more setae. From the $10^{\text {th }}$ stage on, there was presence of bulges on $\mathrm{PL}_{1}$ distally. Morphology of $12^{\text {th }}$ stage pleopods was the same as seen in adults.
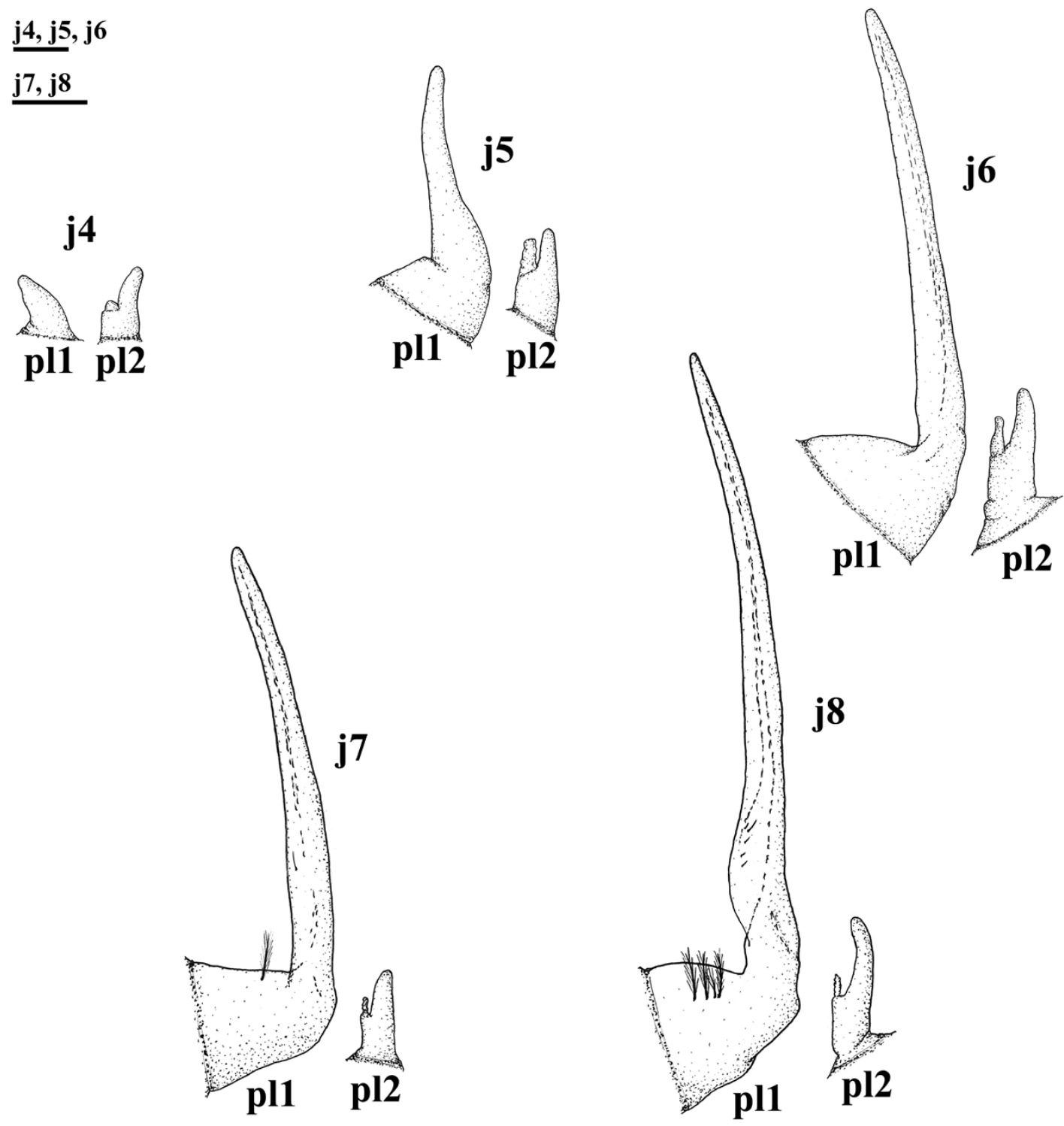

Figure 6 - Callinectes danae. pl1 and pl2: pleopods of the $1^{\text {st }}$ and $2^{\text {nd }}$ male abdominal somites, respectively, from $4^{\text {th }}(\mathbf{j} 4), 5^{\text {th }}(\mathbf{j} 5)$, $6^{\text {th }}(\mathbf{j} 6), 7^{\text {th }}(\mathbf{j} 7)$ and $8^{\text {th }}(\mathbf{j} 8)$ stages on. Scale: $\mathbf{j} 4, \mathbf{j 5}$ and $\mathbf{j 6}, 0.1 \mathrm{~mm} ; \mathbf{j} 7$ and $\mathbf{j 8}, 0.2 \mathrm{~mm}$. 


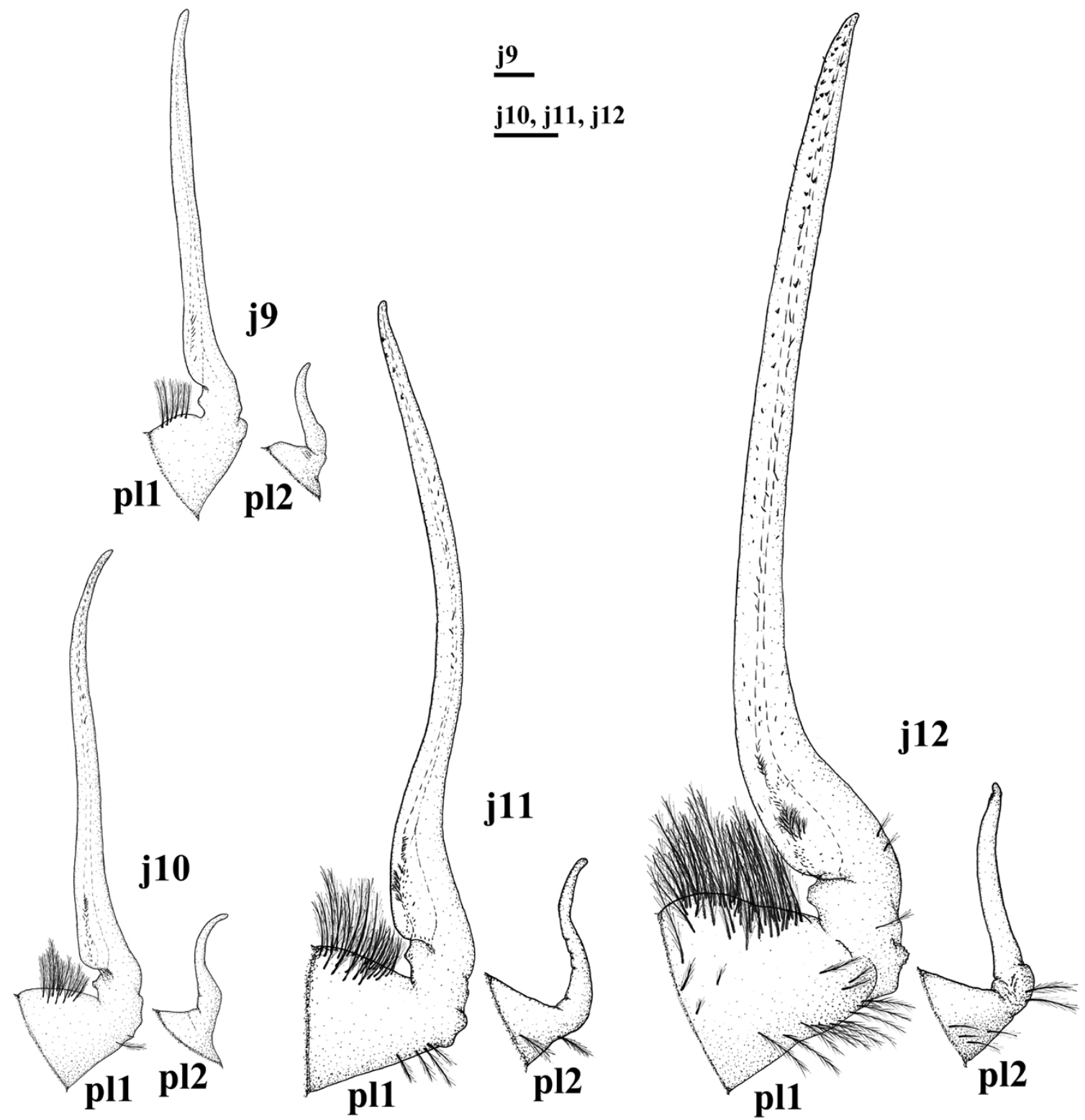

Figure 7 - Callinectes danae. pl1 and pl2: pleopods of the $1^{\text {st }}$ and $2^{\text {nd }}$ male abdominal somites, respectively, from $9^{\text {th }}(\mathbf{j} 9), 10^{\text {th }}(\mathbf{j} 10)$, $11^{\text {th }}(\mathbf{j} 11)$ and $12^{\text {th }}(\mathbf{j} 12)$ stages on. Scale: $\mathbf{j} \mathbf{9}, 0.2 \mathrm{~mm} ; \mathbf{j 1 0}, \mathbf{j 1 1}$ and $\mathbf{j 1 2}, 0.4 \mathrm{~mm}$.

Female: four biramous pleopods from the $2^{\text {nd }}$ to the $5^{\text {th }}$ abdominal somite $\left(\mathrm{PL}_{2}, \mathrm{PL}_{3}, \mathrm{PL}_{4}\right.$ and $\mathrm{PL}_{5}$ ); simple setae on endopod of $\mathrm{PL}_{2}$ and $\mathrm{PL}_{3}$ only (Fig. 8, $\mathrm{J}_{4}$ ). $5^{\text {th }}$ stage pleopods (Fig. 8, $\mathrm{J}_{5}$ ) were larger, with more setae. In the $6^{\text {th }}$ stage (Fig. $8, \mathrm{~J}_{6}$ ), $\mathrm{PL}_{2}$ endopod segmentation begun, a few brushshaped setae on $\mathrm{PL}_{2}$ and $\mathrm{PL}_{3}$. In the $7^{\text {th }}$ and $8^{\text {th }}$ stages (Fig. 8, $\mathrm{J}_{7}$ and $\mathrm{J}_{8}$ ), number of brush-shaped setae increased, endopod of all pleopods gradually was larger and more segmented. In the $9^{\text {th }}$ stage (Fig. 9, J9), there were simple articulated setae (instead of brush-shaped setae) on the endopod of all pleopods. From the $10^{\text {th }}$ stage on, pleopods were very similar to those of adults, with simple articulated setae larger and more abundant in later stages (Fig. 9, $\mathrm{J}_{10}-\mathrm{J}_{12}$ ). 

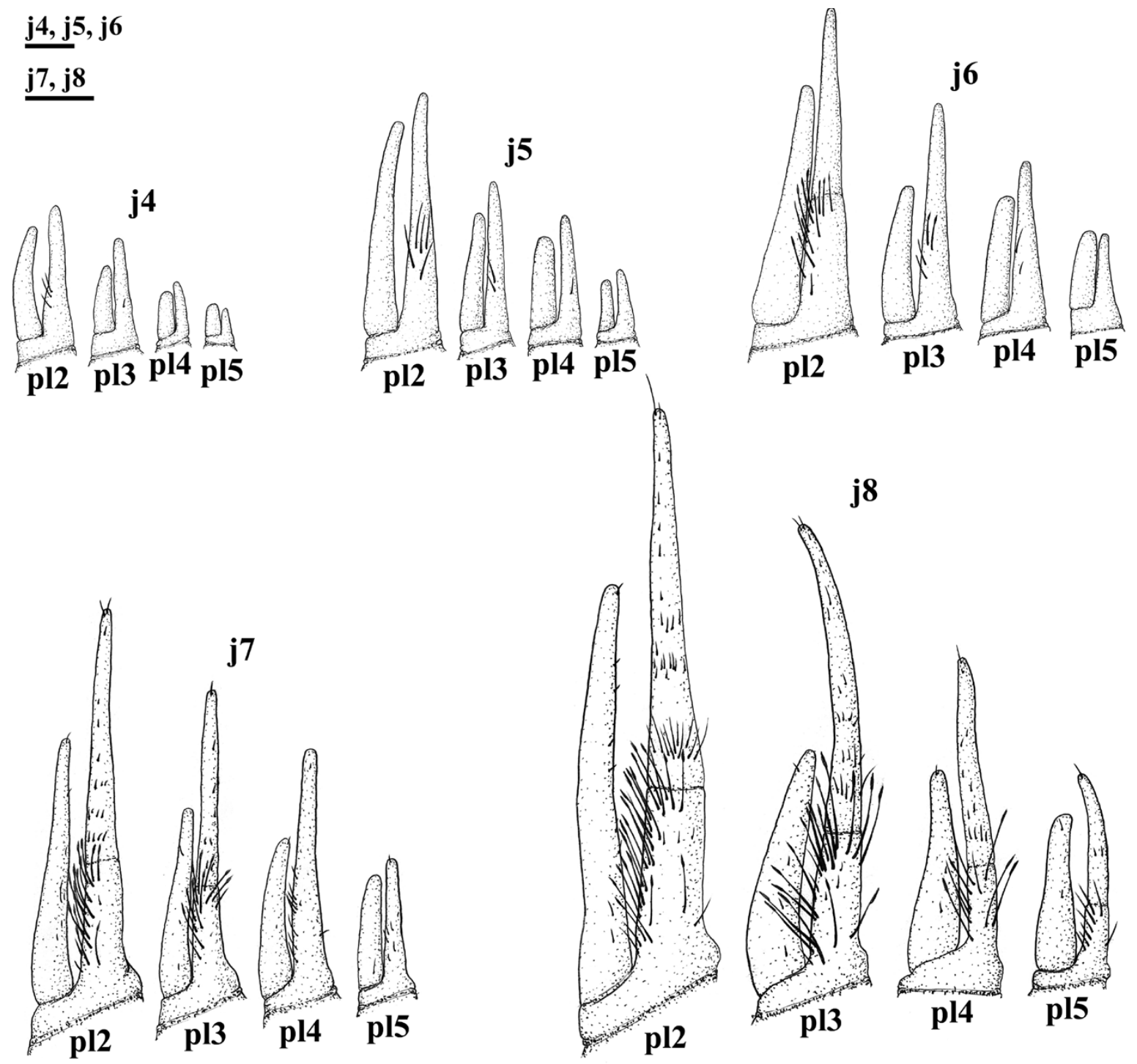

Figure 8 - Callinectes danae. pl2 to pl5: pleopods from the $2^{\text {nd }}$ to $5^{\text {th }}$ female abdominal somites, respectively, from $4^{\text {th }}(\mathrm{j} 4), 5^{\text {th }}(\mathrm{j} 5)$, $6^{\text {th }}(j 6), 7^{\text {th }}(j 7)$ and $8^{\text {th }}(j 8)$ stages on. Scale: $j 4, j 5$ and $j 6,0.1 \mathrm{~mm}$; $j 7$ and $j 8,0.2 \mathrm{~mm}$.

In the remaining body structures, some significant changes occurred in the following: 1) Endopod of first maxilliped had a hollow in the apical region and a foliaceous shape on the internal margin from the $2^{\text {nd }}$ stage on; 2) First segment of the antennal peduncle had a projection similar to the antennal scale, mainly from the most advanced stages on.

Other appendages did not show remarkable morphological changes, but the number of setae increased on each segment of the appendages. On the epipod of the third maxilliped, some denticle- serrulate harpoon-shaped setae appeared from the $3^{\text {rd }}$ stage on. Such setae were also found on the epipod of the $2^{\text {nd }}$ maxilliped from the $4^{\text {th }}$ stage on, and on the epipod of the $1^{\text {st }}$ maxilliped in the $5^{\text {th }}$ stage.

The main morphological characteristics which allow the identification of the first 12 stages of $C$. danae are shown in Table II.

The vestigial aperture of the female gonopores appeared from the $4^{\text {th }}$ stage on (Fig. 10a, white arrow). In males, it was not possible to verify in what stage the gonopores appeared. 


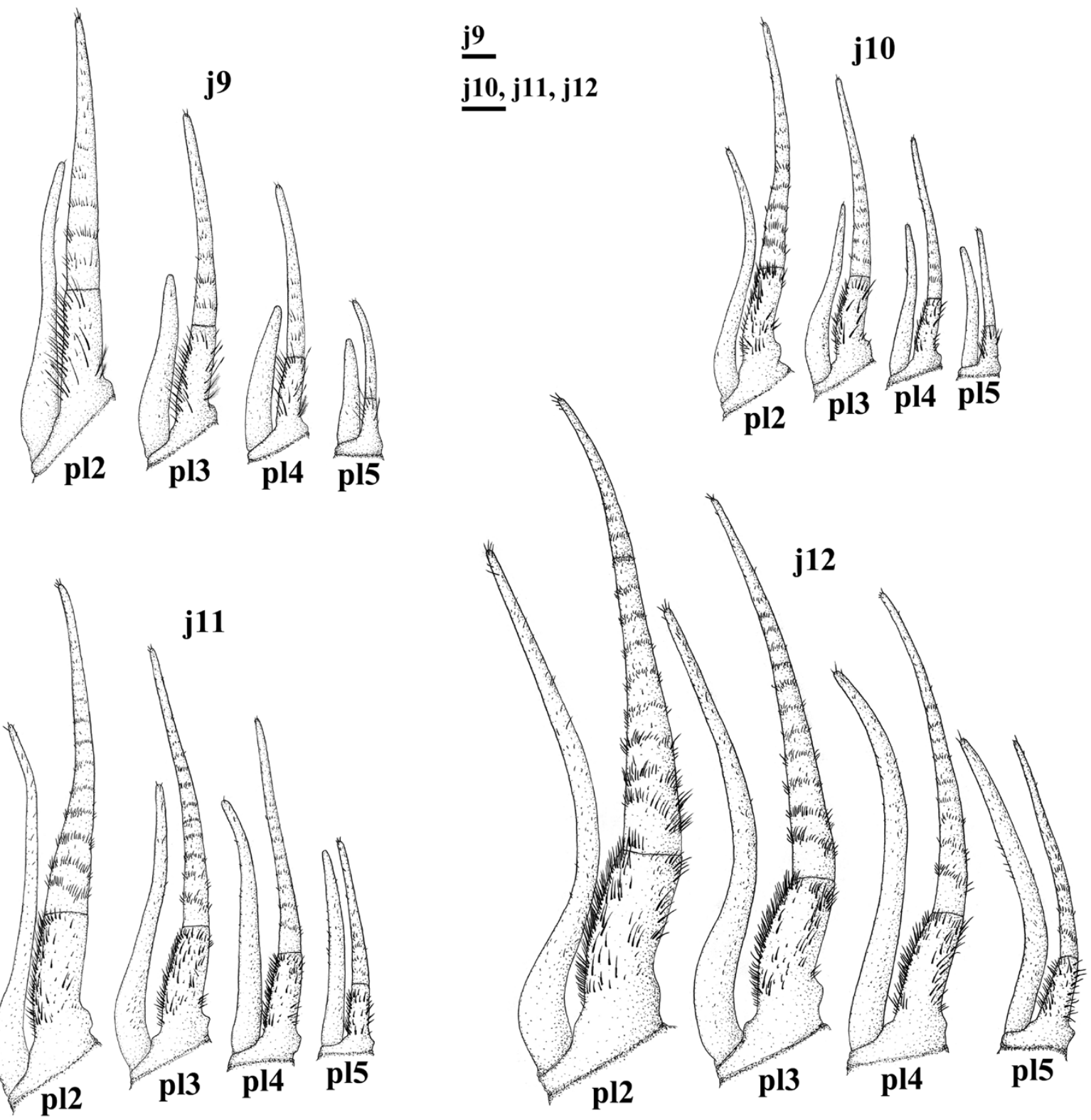

Figure 9 - Callinectes danae. pl2 to pl5: pleopods from the $2^{\text {nd }}$ to $5^{\text {th }}$ female abdominal somites, respectively, from $9^{\text {th }}(\mathbf{j} 9)$, $10^{\text {th }}$ $(\mathbf{j} 10), 11^{\text {th }}(\mathbf{j} 11)$ and $12^{\text {th }}(\mathbf{j} 12)$ stages on. Scale: $\mathbf{j} 9,0.2 \mathrm{~mm} ; \mathbf{j 1 0}, \mathbf{j 1 1}$ and $\mathbf{j 1 2}, 0.4 \mathrm{~mm}$.

The abdomen remained sealed throughout the stages observed. Detailed inspection revealed two pairs of "closing mechanisms" or "sternal buttons" on the sternal plates: an anterior one (located on the $5^{\text {th }}$ sternite, at the level of the distal region of the $6^{\text {th }}$ abdominal somite) (Fig. 10a, black arrow); and another, posterior one (located on the $8^{\text {th }}$ sternite, at the level of the lateral region of the $2^{\text {nd }}$ abdominal somite) (Fig. 10b, black arrow), which did not allow the extension of the abdomen.

\section{DISCUSSION}

The post-larval development of only a few species of portunid crabs is known to date. Lebour (1944) presented brief descriptions of the carapace of the first undifferentiated stage of Portunus anceps 
TABLE II

Callinectes danae Smith, 1869. The main morphological characteristics for the identification of the first 12 stages of the juvenile phase. The dimensions were taken in millimeters and represent mean values. Numbers in parenthesis mean alternative values with low occurrences.

\begin{tabular}{|c|c|c|c|c|c|c|c|c|c|c|c|c|}
\hline Characteristics & J1 & $\mathrm{J} 2$ & $\mathrm{~J} 3$ & J4 & $\mathrm{J} 5$ & J6 & $\mathrm{J} 7$ & J8 & J9 & $\mathrm{J} 10$ & J11 & $\mathrm{J} 12$ \\
\hline $\begin{array}{l}\text { Number of segments } \\
\text { on antennule endopod }\end{array}$ & 2 & 2 & 3 & 3 & 3 & 4 & 4 & 4 & 5 & 5 & 5 & 6 \\
\hline $\begin{array}{l}\text { Number of segments } \\
\text { on antennule exopod }\end{array}$ & 7 & 8 & 9 & 10 & 11 & 12 & 13 & 14 & 15 & 16 & $18(19)$ & 20 \\
\hline $\begin{array}{l}\text { Number of segments } \\
\text { of antennal flagellum }\end{array}$ & 10 & 10 & 12 & 13 & 18 & 20 & 22 & $24(23)$ & $29(30)$ & 32 & $34(33)$ & 39 \\
\hline Antenna length & 1.29 & 1.42 & 1.9 & 2.27 & 2.96 & 3.62 & 4.51 & 4.98 & 6.07 & 6.86 & 8.4 & 9.58 \\
\hline $\begin{array}{l}\text { Number of setae on the } \\
\text { basis of maxillule protopod }\end{array}$ & 1 & 2 & 2 & 4 & 4 & 4 & 6 & $7(8)$ & $11(10)$ & 12 & $12(13)$ & $13(14)$ \\
\hline $\begin{array}{l}\text { Number of marginal setae } \\
\text { on maxilla exopod }\end{array}$ & \pm 85 & \pm 102 & \pm 148 & \pm 161 & \pm 183 & \pm 229 & \pm 270 & \pm 298 & \pm 325 & \pm 359 & \pm 406 & \pm 425 \\
\hline Length of maxilla exopod & 0.67 & 0.77 & 1.06 & 1.37 & 1.59 & 2.04 & 2.28 & 2.64 & 3.25 & 3.74 & 4.39 & 4.98 \\
\hline $\begin{array}{l}\text { Number of apical setae } \\
\text { on } 1^{\text {st }} \text { maxilliped }\end{array}$ & 11 & 14 & 23 & \pm 33 & \pm 38 & \pm 49 & \pm 65 & \pm 73 & \pm 81 & \pm 89 & \pm 101 & \pm 112 \\
\hline $\begin{array}{l}\text { Length of basal segment } \\
\text { of } 1^{\text {st }} \text { maxilliped exopod }\end{array}$ & 0.62 & 0.74 & 0.92 & 1.16 & 1.36 & 1.69 & 1.98 & 2.18 & 2.57 & 2.92 & 3.55 & 4.14 \\
\hline $\begin{array}{l}\text { Length of basal segment } \\
\text { of } 2^{\text {nd }} \text { maxilliped exopod }\end{array}$ & 0.64 & 0.74 & 0.96 & 1.23 & 1.42 & 1.82 & 2.12 & 2.29 & 2.73 & 3.2 & 3.89 & 4.46 \\
\hline $\begin{array}{l}\text { Length of basal segment } \\
\text { of } 3^{\text {rd }} \text { maxilliped exopod }\end{array}$ & 0.63 & 0.75 & 0.92 & 1.18 & 1.35 & 1.71 & 1.96 & 2.15 & 2.62 & 3.02 & 3.59 & 4.11 \\
\hline Length of $2^{\text {nd }}$ pereiopod merus & 0.95 & 1.14 & 1.64 & 2.13 & 2.56 & 3.37 & 3.82 & 4.33 & 5.38 & 6.12 & 7.42 & 8.91 \\
\hline
\end{tabular}

\pm indicates "approximately".

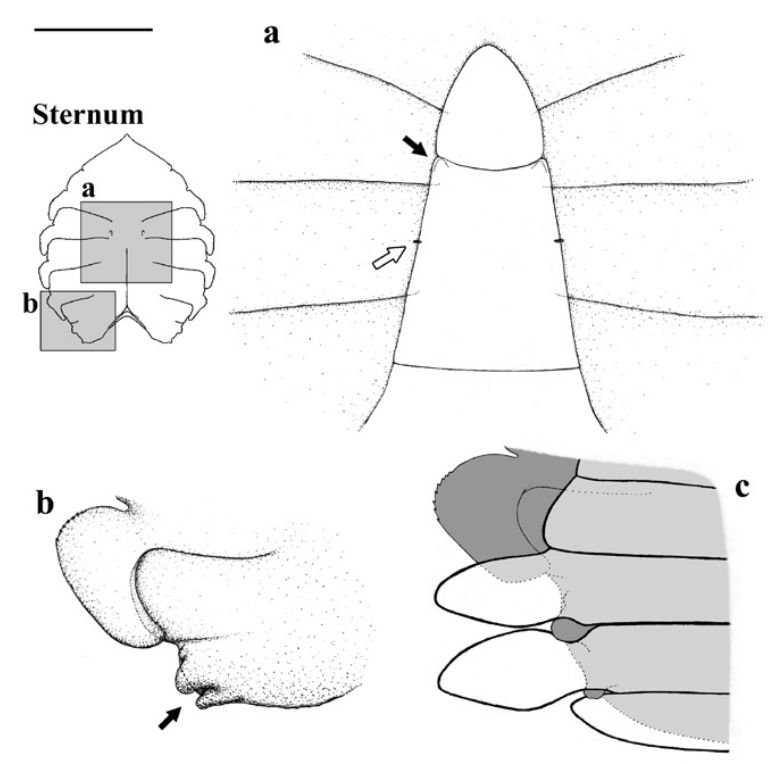

Figure 10 - Callinectes danae, $4^{\text {th }}$ stage of the juvenile phase: A, white arrow, the rudimentary female gonopores; black arrow, anterior "closing mechanism" position; B, posterior "closing mechanism" position, pointed by the arrow; C, schematic drawing of the position of the abdomen over the posterior "closing mechanism".
(Saussure 1858), and found 8 lateral spines in addition to the pair that is common to portunid crabs. Yatsuzuka and Sakai (1980) also described the first undifferentiated stage of $P$. pelagicus, which showed the same characteristics as $P$. anceps and also a serrate rostrum. Only C. ornatus (studied by Bolla Jr et al. 2008), C. similis (studied by Ogburn et al. 2011) and C. danae (present study) have been reported bearing a similar serrate rostrum starting from the first undifferentiated stage. In C. sapidus, according to Barutot et al. (2001) and Ogburn et al. (2011), the rostrum is smooth in the first undifferentiated stage, and the spines appear only as of the $6^{\text {th }}$ stage. This feature might be useful as a diagnostic of this species on the Brazilian coast, as it is easy to distinguish. Nevertheless, further studies on other species of the genus Callinectes are needed.

Morphological descriptions of juvenile forms are mainly based on the number of segments and 
setae on the body appendages. However, because of the difficulty in discerning characteristics in the morphology of different setae types with only optical microscopy, the study of setae in the juvenile phases has been limited to counting them and noting their location on the animal's body (Rieger and Beltrão 2000).

Certain appendages and morphological features have proven to be highly useful in discriminating species, due to their particularities, which can be observed with minimal manipulation of the specimens. These will likely prove to be useful for future comparisons and species identifications. Among these are the following features: number of segments of the antennal flagellum (i.e., C. sapidus, C. danae and C. ornatus, which have 8, 10 and 10(11) segments, respectively), and the number of setae on the maxilla and on the $1^{\text {st }}, 2^{\text {nd }}$ and $3^{\text {rd }}$ maxillipeds.

With regards to the sternal region, the presence of wrinkles in concentric semicircles on the $7^{\text {th }}$ somite of the first undifferentiated stage [present in $C$. danae and C. ornatus, but not noted by Yatsuzuka and Sakai (1980) and Barutot et al. (2001) in P. pelagicus (Linnaeus, 1758) and $C$. sapidus, respectively], could be interpreted as a remnant of the sternal spine that is conspicuous in the portunid megalopa (Kurata 1975). Such wrinkles are not found in the next stages, reinforcing this supposition. Nevertheless, further studies are needed in order to confirm the origin of this feature.

As mentioned by Guinot and Bouchard (1998), the anterior abdomen sealing mechanism, located on the $5^{\text {th }}$ thoracic sternite of $C$. danae, is in accordance with the typical system of sealing found in the Eubrachyura. However, those authors did not mention the closing mechanism ( $8^{\text {th }}$ sternite). This mechanism may be exclusive to portunids, but only through additional studies of species within and outside the family would this hypothesis be able to be tested.

The sexual dimorphism in the abdominal shape of males and females is not evident throughout the juvenile phase observed for $C$. danae. For $C$. sapidus, C. ornatus and P. pelagicus, studied up to the $11^{\text {th }}, 11^{\text {th }}$ and $3^{\text {rd }}$ juvenile stages, respectively, such dimorphism is also not observed. This feature probably develops in later immature stages, in contrast to representatives of other families, in which the sexual differentiation observed in the abdomen is most pronounced in the early immature stages. Examples include Inachus dorsettensis (Pennant 1777), a majid studied by Ingle (1977); P. transversus, a grapsid studied by Flores et al. (1998); and C. angulatus, a varunid studied by Rieger and Beltrão (2000); in which this differentiation occurs from the $3^{\text {rd }}, 6^{\text {th }}$, and $4^{\text {th }}$ immature stages on, respectively.

The presence of the rudimentary pleopods in the first undifferentiated stage can also differ among species; this feature is observed in C. danae, C. ornatus and $P$. pelagicus, but not in $C$. sapidus. Nevertheless, except for $P$. pelagicus which shows rudimentary pleopods up to the $3^{\text {rd }}$ undifferentiated stage, in all other species studied, these pleopods totally disappear by the $2^{\text {nd }}$ undifferentiated stage. This feature might be interpreted as a remnant characteristic from the megalopa stage, since they occupy the same location on somites of the megalopa pleopods. In the following stages, the pleopods appear in accordance with each sex (two pairs for males, and four pairs for females), and the juvenile stage in which such appearance can be observed varies for each species, as shown in Table I. In portunids, the pleopods commonly appear in the $4^{\text {th }}$ stage of the juvenile phase, as in C. danae, C. ornatus and C. sapidus.

A distinctive and interesting feature with regards to the $2^{\text {nd }}$ pair of pleopods of males $\left(\mathrm{PL}_{2}\right)$ is the fact that this appendage is biramous until the $8^{\text {th }}$ stage in $C$. danae and until the $6^{\text {th }}$ stage in C. ornatus, and, at least, until the $7^{\text {th }}$ stage in $C$. sapidus (as can be seen in Barutot et al. 2001). More interesting yet is the fact that only $C$. sapidus has a biramous first pleopod $\left(\mathrm{PL}_{1}\right)$ in males. In the remaining portunid species studied, the $\mathrm{PL}_{1}$ remains uniramous as of its first appearance in juveniles. 
Table III presents a comparative analysis, using the main morphological characteristics, among the species of the genus Callinectes which occur on the Brazilian coast and for which their juvenile development is known to date.

It is of great importance to consider further studies on the early phases of decapod crustacean life cycles, for a better understanding of their life history, taxonomy or ecological and functional issues, since these subjects are interconnected. Such studies are also important to define characteristics that are peculiar to the juvenile phase, and they could allow us to identify species for various purposes, notably aquaculture and fisheries management.

TABLE III

Diagnostic characters which allow the differentiation and identification of the first undifferentiated stage of the known species of the genus Callinectes with regards to juvenile phase.

\begin{tabular}{|c|c|c|c|c|}
\hline \multirow{2}{*}{ JUVENILE I } & C. sapidus & C. ornatus & C. danae & \\
\hline & Barutot et al. (2001) & Bolla Jr et al. (2008) & This study & \\
\hline Antennule endopod segments & 2 & 2 & 2 & \\
\hline Antennule exopod segments & 7 & 7 & 7 & \\
\hline Antenna segments & $3+8$ & $3+11$ & $3+10$ & $*$ \\
\hline Mandible palp segments & 3 & 3 & 3 & \\
\hline Maxillule endopod segments & 2 & 2 & 2 & \\
\hline $\begin{array}{l}\text { Maxillule endopod (E), basial endite (EB), } \\
\text { coxal endite (EC), protopod (P) setae }\end{array}$ & $\begin{array}{l}4,2(\mathrm{E}) ; 23 \text { to } 25(\mathrm{~EB}) \\
15 \text { to } 17(\mathrm{EC}) ; 2(\mathrm{P})\end{array}$ & $\begin{array}{l}3,4(\mathrm{E}) ; 29(\mathrm{~EB}) \\
\quad 20(\mathrm{EC}) ; 3(\mathrm{P})\end{array}$ & $\begin{array}{l}4,5(\mathrm{E}) ; 30(\mathrm{~EB}) \\
19(\mathrm{EC}) ; 2(\mathrm{P})\end{array}$ & \\
\hline $\begin{array}{l}\text { Maxilla exopod (Ex), endopod (E), basial } \\
\text { endite (EB), coxal endite (EC) marginal setae }\end{array}$ & $\begin{array}{l}60 \text { to } 70(\mathrm{Ex}) ; 0(\mathrm{E}) ; 20 \text { to } \\
23(\mathrm{~EB}) ; 10 \text { to } 13 \text { (EC) }\end{array}$ & $\begin{array}{c}88(\mathrm{Ex}) ; 4(\mathrm{E}) \\
22(\mathrm{~EB}) ; 13(\mathrm{EC})\end{array}$ & $\begin{array}{c}85(\mathrm{Ex}) ; 5(\mathrm{E}) \\
26(\mathrm{~EB}) ; 15(\mathrm{EC})\end{array}$ & $*$ \\
\hline $1^{\text {st }}$ maxilliped exopod segments & 2 & 2 & 2 & \\
\hline $1^{\text {st }}$ maxilliped endopod segments & 1 & 1 & 1 & \\
\hline $\begin{array}{l}1^{\text {st }} \text { maxilliped exopod (Ex), endopod (E), } \\
\text { basial endite (EB), coxal endite (EC), } \\
\text { epipod (Ep) setae }\end{array}$ & $\begin{array}{l}16 \text { to } 19(\mathrm{Ex}) ; 17(\mathrm{E}) \\
38 \text { to } 44(\mathrm{~EB}) ; 17 \text { to } \\
21(\mathrm{EC}) ; 39(\mathrm{Ep})\end{array}$ & $\begin{array}{l}29(\mathrm{Ex}) ; 35(\mathrm{E}) \\
67(\mathrm{~EB}) ; 26(\mathrm{EC}) \\
\text { 49(Ep) }\end{array}$ & $\begin{array}{c}32(\mathrm{Ex}) ; 35(\mathrm{E}) ; 58 \\
(\mathrm{~EB}) ; 33(\mathrm{EC}) ; 58(\mathrm{Ep})\end{array}$ & \\
\hline $2^{\text {nd }}$ maxilliped exopod segments & 2 & 2 & 2 & \\
\hline $\begin{array}{l}2^{\text {nd }} \text { maxilliped exopod (Ex), endopod (E), } \\
\text { epipod (Ep) setae }\end{array}$ & $\begin{array}{l}25 \text { to } 27(\mathrm{Ex}) ; 12 \\
2,3,12 \text { to } 14(\mathrm{E})\end{array}$ & $\begin{array}{c}52(\mathrm{Ex}) ; 27,8,14 \\
14(\mathrm{E}) ; 6(\mathrm{Ep})\end{array}$ & $\begin{array}{l}44(\mathrm{Ex}) ; 11,24,6 \\
15,14(\mathrm{E}) ; 3(\mathrm{Ep})\end{array}$ & $*$ \\
\hline $3^{\text {rd }}$ maxilliped exopod segments & 2 & 2 & 2 & \\
\hline $\begin{array}{l}3^{\text {rd }} \text { maxilliped exopod (Ex), protopod (P), } \\
\text { epipod (Ep) setae }\end{array}$ & $\begin{array}{l}18 \text { to } 20(\mathrm{Ex}) ; 14 \text { to } \\
17(\mathrm{P}) ; 22 \text { to } 24(\mathrm{Ep})\end{array}$ & $\begin{array}{l}56(\mathrm{Ex}) ; 16(\mathrm{P}) \\
28(\mathrm{Ep})\end{array}$ & $\begin{array}{l}79(\mathrm{Ex}) ; 66(\mathrm{P}) \\
68(\mathrm{Ep})\end{array}$ & $*$ \\
\hline Number of pleopods & 0 & 4 rudimentary pairs & 4 rudimentary pairs & $*$ \\
\hline
\end{tabular}

* = most important characteristics for comparison among species.

\section{ACKNOWLEDGMENTS}

The authors are grateful to Conselho Nacional de Desenvolvimento Científico e Tecnológico (CNPq) for the first author's Master of Science scholarship (\# 553174/2008-8), to Fundação de Amparo à Pesquisa do Estado de São Paulo (FAPESP) for providing the financial support during neuston collections (\#2004/15194-6), to all the members of NEBECC for their assistance during this study, and to Dr. Janet W. Reid for her help with the English review. All sampling in this investigation has been conducted in accordance with applicable state and federal Brazilian laws.

\section{RESUMO}

O desenvolvimento juvenil de Callinectes danae foi investigado a partir de megalopas obtidas em amostras de neuston em Ubatuba, São Paulo, Brasil. Os indivíduos foram criados em laboratório sob temperatura constante $\left(25 \pm 1^{\circ} \mathrm{C}\right)$, água do mar filtrada proveniente do local de coleta (35\%) e fotoperíodo natural. Nauplii recém-eclodidos de Artemia sp. foram oferecidos diariamente como base de alimento 
e também ração de peixes ornamentais foi fornecida a juvenis a partir do $4^{\circ}$ estágio. Foram obtidos 12 estágios da fase juvenil. As principais características morfológicas que permitiram o reconhecimento do primeiro estágio juvenil foram desenhadas e descritas. Todos os estágios subsequentes obtidos foram analisados e medidos, e as principais alterações em relação ao primeiro estágio foram registradas. O dimorfismo sexual torna-se evidente a partir do $4^{\circ}$ estágio juvenil. Alguns apêndices e características morfológicas provaram ser de grande importância para identificação das espécies, incluindo o número de segmentos do flagelo antenal e o número de cerdas na maxila e no $1^{\circ}$, $2^{\circ}$ e $3^{\circ}$ maxilípedes. Estes, provavelmente, podem ser usados para futuras comparações e identificações de espécies.

Palavras-chave: estágios juvenis, morfologia, portunídeos, pós-larva, siri.

\section{REFERENCES}

ANGER K. 2001. The Biology of Decapod Crustacean Larvae (Crustacean Issues 14). Lisse: A. A. Balkema Publishers, 419 p.

BARUTOT RA, VIEIRA RRR AND RIEGER PJ. 2001. Desenvolvimento juvenil de Callinectes sapidus Rathbun, 1896 (Crustacea: Decapoda: Portunidae), em laboratório, a partir de megalopas coletadas no plâncton. Comun Mus Cienc Tecnol PUCRS, Ser Zool 14: 23-42.

Bolla Jr EA, Negreiros-Fransozo ML and Fransozo A. 2008. Juvenile development of Callinectes ornatus Ordway, 1863 (Crustacea: Decapoda: Portunidae), from megalopae obtained from neuston samples. Zootaxa 1788 : $1-20$.

CALADO TCS. 1996. Registro de Charybdis hellerii (Milne Edwards, 1867) em águas de litoral brasileiro (Decapoda: Portunidae). Bol Estud Cienc Mar 9: 175-180.

CARQueIJA CRG AND GouvÊA EP. 1996. A ocorrência, na costa brasileira, de um Portunidae (Crustacea, Decapoda) originário do Indo-Pacífico e Mediterrâneo. Nauplius 4: 165-168.

Clark PF, Calazans DD and Pohle GW. 1998. Accuracy and standardization of brachyuran larval descriptions. Invertebr Reprod Dev 33: 127-144.

DineEn JF, Clark PF, Hines AH, ReEd SA AND WALton HP. 2001. Life history, larval description, and natural history of Charybdis hellerii (Decapoda, Brachyura, Portunidae), an invasive crab in the Western Atlantic. J Crust Biol 21: 774-805.

FELDER DL, MARTIN JW AND GOY JW. 1985. Patterns in early post-larval development of decapods. In: WENNER AM (Ed), Larval Growth, Crustacean Issues, vol. 2, Rotterdam: Balkema Press, Rotterdam, Netherlands, p. 163-225.
Flores AAV, MARQUES FPL AND NEGREIROS-FrAnSOZO ML. 2002. Postlarval stages and growth patterns of the spider crab Pyromaia tuberculata (Brachyura, Majidae) from laboratory-reared material. J Crust Biol 22: 314-327.

Flores AAV, Negreiros-Fransozo ML AND Fransozo A. 1998. The megalopa and juvenile development of Pachygrapsus transversus (Gibbes, 1850) (Decapoda, Brachyura), compared with other grapsid crabs. Crustaceana 71: 197-222.

Fransozo A. 1986/87. Desenvolvimento dos estágios juvenis de Sesarma (Holometopus) rectum Randall, 1840 (Decapoda, Grapsidae) obtidos em laboratório. Naturalia 12: 77-87.

Fransozo A AND NEGreiros-Fransozo ML. 1987. Morfologia dos primeiros estágios juvenis de Eriphia gonagra (Fabricius, 1781) e Eurypanopeus abbreviatus (Stimpson, 1860) (Crustacea, Decapoda, Xanthidae), obtidos em laboratório. Pap Avulsos Zool 36: 257-277.

Fransozo A, Negreiros-Fransozo ML AND Hiyodo CM. 1988. Développement juvénile de Menippe nodifrons Stimpson, 1859 (Crustacea, Decapoda, Xanthidae) au laboratoire. Rev Hydrobiol Trop 21: 297-308.

GARM A. 2004. Revising the definition of the crustacean seta and setal classification systems based on examinations of the mouthpart setae of seven species of decapods. Zool J Linn Soc 142: 233-252.

GuimarÃES FJ AND NEGREIROS-FrANSOZO ML. 2005. Juvenile development and growth patterns in the mud crab Eurytium limosum (Say, 1818) (Decapoda, Brachyura, Xanthidae) under laboratory conditions. J Nat Hist 39: 2145-2161.

GUINOT D AND BOUCHARD J-M. 1998. Evolution of the abdominal holding systems of brachyuran crabs (Crustacea, Decapoda, Brachyura). Zoosystema 20: 613-694.

HARTNOLL RG. 1982. Growth. In: BLISS DE (Ed), The biology of Crustacea: embryology, morphology and genetics, vol. 2, New York: Academic Press Inc, New York, USA, p. 111-185.

Hebling NJ, Fransozo A And Negreiros-Fransozo ML. 1982. Desenvolvimento dos primeiros estágios juvenis de Panopeus herbstii H. Milne-Edwards. 1834 (Crustacea, Decapoda, Xanthidae), criadas em laboratório. Naturalia 7: 177-188.

Hebling NJ And Rieger PJ. 2003. Desenvolvimento juvenil de Hepatus pudibundus (Herbst) (Crustacea, Decapoda, Calappidae), em laboratório. Rev Bras Zool 20: 531-539.

Hirose GL, Bolla JR EA AND Negreiros-Fransozo ML. 2010. Post-larval morphology, growth, and development of Uca cumulanta Crane, 1943 (Crustacea, Decapoda, Ocypodidae) under laboratory conditions. Invertebr Reprod Dev 54: 95-109.

INGLE RW. 1977. The larval and post-larval development of the scorpion spider crab, Inachus dorsettensis (Pennant) (Family: Majidae), reared in the laboratory. Bull Br Mus Nat Hist Zool 3: 331-348.

KURATA H. 1962. Studies on the age and growth of Crustacea. Bull Hokkaido Reg Fish Res Lab 24: 1-115. 
KURATA H. 1975. Larvae of Decapoda Brachyura of Arasaki, Sagami Bay-V. The swimming crabs of subfamily Portuninae. Bull Nansei Reg Fish Res Lab 8: 39-65.

LeBour MV. 1944. Larval Crabs from Bermuda. Zoologica 29: 113-128.

MARtin JW, Felder DL AND TRUesdale FM. 1984. A comparative study of morphology and ontogeny in juvenile stages of four western Atlantic xanthoid crabs (Crustacea: Decapoda: Brachyura). Phil Trans R Soc Lond B 303: 537-604.

MELo GAS. 1996. Manual de Identificação dos Brachyura (Caranguejos e Siris) do Litoral Brasileiro. São Paulo: Plêiade/FAPESP, 603 p.

Negreiros-Fransozo ML, Fernandes CS, Silva SMJ AND FRANSOZO A. 2011. Early juvenile development of Armases rubripes (Rathbun 1897) (Crustacea, Brachyura). Invertebr Reprod Dev 2011: 1-12.

Negreiros-Fransozo ML and Fransozo V. 2003. Morphometric study of the mud crab, Panopeus austrobesus Williams, 1983 (Decapoda, Brachyura) from a subtropical mangrove in South America. Crustaceana 76: 281-294.

Negreiros-Fransozo ML, WenNer EL, KNOtT D AND FrANSOZO A. 2007. The megalopa and early juvenile stages of Calappa tortugae Rathbun, 1933 (Crustacea, Brachyura) reared in laboratory from neuston samples. Proc Biol Soc Wash 120: 469-485.

NG PKL, Guinot D AND DAVIE PJF. 2008. Systema Brachyurorum: Part I. An annotated checklist of extant brachyuran crabs of the world. Raffles Bull Zool Suppl 17: 1-286.

Ogburn MB, Stuck KC, HeArd RW, WANG SY AND FORWARD JR RB. 2011. Seasonal variability in morphology of blue crab, Callinectes sapidus, megalopae and early juvenile stage crabs, and distinguishing characteristics among co-occurring Portunidae. J Crust Biol 31: 106-113.

PAUla J AND HARTNOLL RG. 1989. The larval and post-larval development of Percnon gibbesi (Crustacea, Brachyura, Grapsidae) and the identity of the larval genus Pluteocaris. J Zool 218: 17-37.
POHLE G. 1989. Structure, function, and development of setae on gill-grooming appendages and associated mouthparts of pinnotherid crabs (Decapoda: Brachyura). Can J Zool 67: 1690-1707.

Pohle G, MANTElatTo FLM, NeGREIROS-FrANSOZO ML AND FrANSOZO A. 1999. Decapod larvae. In: BOLTOVSKOY D (Ed), South Atlantic Zooplankton, vol. 2, Rotterdam: Balkema Books, Rotterdam, Netherlands, p. 1281-1351.

RIEGER PJ AND BELTRÃo R. 2000. Desenvolvimento juvenil de Cyrtograpsus angulatus Dana (Crustacea, Decapoda, Grapsidae), em laboratório. Rev Bras Zool 17: 405-420.

RiEGER PJ AND NAKAGaWA C. 1995. Desenvolvimento juvenil de Chasmagnathus granulata Dana, 1851 (Crustacea, Decapoda, Grapsidae) em laboratório. Nauplius 3: 59-74.

SHEN CJ. 1935. An Investigation of the Post-Larval Development of the Shore-Crab Carcinus maenas, with Special Reference to the External Secondary Sexual Characters. Proc Zool Soc Lond 1935: 1-33.

StUCK KC AND TRUESDALE FM. 1988. Larval development of the speckled swimming crab, Arenaeus cribrarius (Decapoda: Brachyura: Portunidae) reared in the laboratory. Bull Mar Sci 42: 101-132.

TAVARES M AND MENDONÇA JR JB. 1996. Charybdis hellerii (A. Milne Edwards, 1867) (Brachyura: Portunidae), eighth nonindigenous marine decapod recorded from Brazil. Crustaceana Res 25: 151-207.

VIEIRA RRR, PINHO GLL AND RIEGER PJ. 2010. Juvenile development of Uca (Minuca) burgersi Holthuis, 1967 (Crustacea, Brachyura, Ocypodidae) in the laboratory. Atlântica 32: 59-70.

YATSUZUKA K AND SAKAI K. 1980. The larvae and juvenile crabs of Japanese Portunidae (Crustacea, Brachyura). I Portunus (Portunus) pelagicus (Linné). Rep Usa Mar Biol Inst Kochi Univ 2: 25-41. 